Jurnal Media Pertanian Vol. 4 No. 1 Tahun 2019 Hal. 8 - 18

Media Komunikasi Hasil Penelitian dan Review Literatur Bidang Ilmu Agronomi ISSN print $2503-1279$

ISSN online $2581-1606$

\title{
NISBAH KESETARAHAN LAHAN POLIKULTUR PINANG (Areca catechu L.) DENGAN KELAPA DALAM (Cocos nucifera L.) DAN PINANG DENGAN KELAPA SAWIT (Elaeis guineensis Jacq)
}

\author{
${ }^{1}$ Rudi Hartawan dan ${ }^{2}$ Fathul Hariadi \\ ${ }^{1}$ Prodi Agroteknologi, Fakultas Pertanian Universitas Batanghari \\ ${ }^{2}$ Alumni Prodi Agroteknologi, Fakultas Pertanian Universitas Batanghari \\ Jl. Slamet Riyadi, Broni Jambi, 36122. Telp. +62741 60103 \\ 'email korespondensi : rudi2810@yahoo.com
}

\begin{abstract}
Polyculture of Tall Coconut and Palm Oil plants with Areca nut plants is one alternative to increase land productivity and increase farmer's income. The aim of the study was to compare the Land Equivalent Ratio (LER) the polyculture of Areca palm combined with Tall Coconut and Areca Palm combined with Palm Oil. The research was carried out in "Sungai Beras" Village, "Mendahara Ulu" District, East "Tanjung Jabung" Regency in December 2018 - March 2019. Survey methods was used in data collection taken from the farmers' lands planted with monoculture and polyculture among Areca, Tall Coconut, and Palm Oil. The research location was purposely chosen because there was a combine cultivation between Areca Palm with Tall Coconut and between Areca Palm cultivation with Palm Oilat this area. The variables observed were; physical plant and first fruiting, production estimation $\left(\mathrm{kg} \mathrm{ha}^{-1}\right)$, productivity estimation ( $\mathrm{kg} \mathrm{ha}^{-1}$ $\left.t h^{-1}\right)$, and LER. Data obtained were analyzed by descriptive analysis method expressed in tabulation form and inference analysis e.g paired $t$ test of $0.05 \%$ level. The results sowed that the value of Areca Palm LER on polyculture between Areca Palm with Tall Coconutwas 1.19 and Areca Palm with Palm Oil showed 1.10. This data illustrates that Areca Palm and TallCoconut polyculture was 9\% more profitable than Areca Palm Oil and Palm Oil polyculture.

Keywords: Polyculture, LER, Areca Palm, Tall Coconut, Palm Oil.
\end{abstract}

\begin{abstract}
Abstrak
Polikultur tanaman Kelapa Dalam dan Kelapa Sawit dengan tanaman Pinang merupakan salah satu alternatif untuk meningkatkan produktivitas lahan dan meningkatkan pendapatan petani. Penelitian bertujuan untuk membandingkan NKL polikultur Pinang dengan Kelapa Dalam dan Pinang dengan Kelapa Sawit. Pelaksanaan penelitian di Desa Sungai Beras, Kecamatan Mendahara Ulu, Kabupaten Tanjung Jabung Timur pada bulan Desember 2018 sampai Maret 2019. Pengumpulan data mengunakan metode survey pada lahan-lahan petani yang ditanami Pinang, Kelapa Dalam, dan Kelapa Sawit monokultur dan polikultur. Lokasi penelitian di pilih secara sengaja karena pada lokasi-lokasi tersebut terdapat budidaya polikultur Pinang dengan Kelapa Dalam dan Pinang dengan Kelapa Sawit. Peubah yang diamati yaitu; fisik tanaman dan umur berbuah, estimasi produksi $\left(\mathrm{kg} \mathrm{ha}^{-1}\right)$, produktivitas $\left(\mathrm{kg} \mathrm{ha}^{-1} \mathrm{th}^{-1}\right)$. Data yang diperoleh di lapangan dilakukan analisis statistika dengan metode deskriptif dalam bentuk tabulasi dan analisis inferensi dengan uji t berpasangan dengan taraf $\alpha$
\end{abstract}

Diterbitkan oleh Program Studi Agroteknologi Fakultas Pertanian Universitas Batanghari Jambi Halaman 8 
Jurnal Media Pertanian Vol. 4 No. 1 Tahun 2019 Hal. 8 - 18

Media Komunikasi Hasil Penelitian dan Review Literatur Bidang Ilmu Agronomi ISSN print $2503-1279$

ISSN online $2581-1606$

0,05\%. Dari hasil penghitungan nilai NKL diperoleh nilai polikultur Pinang dengan Kelapa Dalam 1,19 dan polikultur Pinang dengan Kelapa Sawit 1,10. Data ini mengambarkan bahwa polikultur Pinang dengan Kelapa Dalam lebih menguntungkan 9\% dibandingkan polikultur Pinang dengan Kelapa Sawit.

Kata kunci : Polikultur, NKL, Pinang, Kelapa Dalam, Kelapa Sawit.

\section{PENDAHULUAN}

Pinang dan Kelapa Dalam merupakan tanaman tradisional di Kabupaten Tanjung Jabung Timur.Pada tahun 2016, luas tanam Pinang di Kabupaten Tanjung Jabung Timur mencapai 8.846 hektar atau 47,45\% dari total luasan di Provinsi Jambi. Luas tanam Kelapa Dalam sebesar 58.765 hektar atau 49,88\% dari total luas di Provinsi Jambi. Pada tahun 2000-an, komoditas Kelapa Sawit menjadi sangat populer dan masyarakat banyak yang membudidayakan komoditas ini. Pada tahun 2017, luas lahan Kelapa Sawit di Kabupaten Tanjung Jabung Timur mencapai 89.018 hektar atau $21,55 \%$ dari total luas yang ada di Provinsi Jambi (Dinas Perkebunan Provinsi Jambi, 2017). Berdasarkan Rencana Pembangunan Perkebunan Provinsi Jambi tahun 2019, komoditi Pinang, Kelapa Dalam, dan Kelapa Sawit termasuk dalam 7 komoditi unggulan perkebunan di Provinsi Jambi.

Usaha untuk mengoptimalkan penggunaan lahan pertanian yang ada dapat dilakukan dengan sistem tanam polikultur. Budidaya Pinang (Areca catechu L.) di Kabupaten Tanjung Jabung Timur dilakukan dengan sistem monokultur dan polikultur. Budidaya polikultur dilakukan dengan tanaman Kelapa Sawit (Elaeis guineensis Jacq.) dan Kelapa Dalam (Cocos nucifera L.). Beets (1990) menyatakan bahwa polikultur merupakan penanaman dua tanaman atau lebih secara bersamaan atau dengan satu interval waktu yang singkat, pada sebidang tanah yang sama. Polikultur merupakan sistem penanaman tanaman secara barisan diantara tanaman semusim dengan tanaman tahunan. Ditambahkan oleh Sopandi dan Trikoesoemaningtyas (2011) bahwa polikultur ditunjukan untuk memanfaatkan lingkungan sebaik-baiknya agar diperoleh produksi yang maksimum. Sistem polikultur dapat diatur berdasarkan sifat-sifat perakaran dan waktu penanaman.

Ketika dua atau lebih jenis tanaman tumbuh bersamaan, masing-masing tanaman harus memiliki ruang yang cukup untuk memaksimumkan kerjasama dan meminimumkan kompetisi. Menurut Amanullah et al. (2016), setiap tanaman menghendaki tingkat kerapatan yang berbeda-beda. Salah satu usaha untuk mengatur kerapatan populasi tanaman adalah dengan mengatur jarak tanam. Menurut Hatta (2015), jarak tanam yang tepat akan memberikan pertumbuhan dan hasil yang maksimum. Jarak tanam yang optimum akan memberikan pertumbuhan bagian atas tanaman yang baik sehingga dapat memanfaatkan lebih banyak cahaya matahari dan pertumbuhan bagian akar yang juga baik sehingga dapat memanfaatkan lebih banyak unsur hara. Sebaliknya, jarak tanam yang terlalu rapat akan mengakibatkan kompetisi antar tanaman dalam hal memperoleh cahaya matahari, air dan unsur hara (Kurniawan, 2012). Akibatnya, pertumbuhan tanaman terhambat dan hasil rendah.

Diterbitkan oleh Program Studi Agroteknologi Fakultas Pertanian Universitas Batanghari Jambi Halaman 9 
Jurnal Media Pertanian Vol. 4 No. 1 Tahun 2019 Hal. 8 - 18

Media Komunikasi Hasil Penelitian dan Review Literatur Bidang Ilmu Agronomi ISSN print $2503-1279$

ISSN online $2581-1606$

Sistem budidaya polikultur diyakini memberikan keuntungan yang lebih tinggi dibandingkan budidaya monokultur. Budidaya polikultur perlu memperhatikan aspek kompetisi tanaman, baik antar spesies maupun intra spesies. Penggunaan jarak tanam yang tepat atau populasi tanaman per hektar menjadi kunci terjadi atau tidaknya persaingan tanaman.Pengukuran peubah populasi tanaman per hektar, pertumbuhan tanaman, serta nisbah kesetaraan lahan dapat digunakan untuk menentukan baik buruknya pelaksanaan budidaya polikultur.

Polikultur Pinang Kelapa Dalam dan Pinang Kelapa Sawit merupakan sebuah kombinasi efektif untuk pemanfaatan lahan. Penanaman Pinang dapat dilakukan diantara barisan Kelapa Dalam dan Kelapa Sawit yang sesuai dengan syarat tumbuhnya. Kesesuaian kebutuhan ruang tumbuh akan memberikan dampak sehingga menghasilkan pertumbuhan dan produksi yang optimal.

Polikultur memiliki beberapa kelebihan di antaranya menghasilkan produksi lebih banyak dari beberapa jenis tanaman, resiko kegagalan kurang dibandingkan monokultur serta dengan banyak kombinasi jenis-jenis tanaman dapat diciptakan stabilitas biologis terhadap serangan hama dan penyakit. Selain memiliki kelebihan, polikultur juga memiliki kekurangan diantaranya adalah terjadinya persaingan unsur hara antar tanaman dan produksi tanaman akan saling menghambat (Taha dan Mahdy, 2014).

Berdasarkan penelitian Nengsih (2016), produksi tanaman kelapa sawit dan karet pola monokultur lebih besar dari sistem polikultur. Berdasarkan penghitungan nilai nisbah kesetaraan lahan (NKL) didapat angka sebesar 1,5. Data ini menggambarkan bahwa terdapat nilai tambah sebesar 50\% bila dilakukan budidaya sistem polikultur. Hasil penelitian Nasamsir dan Irman (2018) menunjukkan produksi tanaman Pinang dan Kelapa Dalam sistem monokultur lebih besar dari sistem polikultur. Namun berdasarkan perhitungan produktivitas lahan, nilai nisbah NKL, sebesar 1,46. Data ini juga menggambarkan bahwa sistem polikultur lebih menguntungkan dibandingkan sistem monokultur. Sejalan dengan penelitian yang didapat oleh Nasamsir dan Harianto (2018) bahwa produksi tanaman pinang sistem polikultur lebih rendah dari sistem monokultur, produksi tanaman kopi sistem polikultur relatif sama dengan sistem tunggal, namum nilai NKL 1,67 yang berarti bahwa bahwa produktivitas lahan sistem polikultur pinang dan kopi mendapat tambahan keuntungan sebesar $67 \%$ dibandingkan sistem monokultur.

Pengukuran produktivitas lahan pada sistem polikultur menggunakan nilai nisbah kesetaraan lahan (NKL). Menurut Mead dan Willey (1980), nisbah kesetaraan lahan adalah jumlah nisbah hasil antara tanaman yang dipolikulturkan terhadap hasil tanaman yang ditanam secara monokultur pada tingkat manajemen yang sama. Nisbah kesetaraan lahan merupakan salah satu cara yang digunakan untuk menghitung produktivitas lahan dari dua atau lebih tanaman yang di polikultur.Pemahaman akan kelebihan dan kekurangan dalam polikultur Pinang Kelapa Dalam dan Pinang Kelapa Sawit disajikan dari pada tulisan ini.

Diterbitkan oleh Program Studi Agroteknologi Fakultas Pertanian Universitas Batanghari Jambi Halaman 10 
Jurnal Media Pertanian Vol. 4 No. 1 Tahun 2019 Hal. 8 - 18

Media Komunikasi Hasil Penelitian dan Review Literatur Bidang Ilmu Agronomi

ISSN online $2581-1606$

\section{METODE PENELITIAN}

Penelitian dilaksanakan pada bulan Desember 2018 sampai Maret 2019 di Desa Sungai Beras Kecamatan Mendahara Ulu Kabupaten Tanjung Jabung Timur.Bahan yang digunakan dalam penelitian ini adalah pertanaman Pinang polikultur Kelapa Dalam yang berumur seragam 10-15 tahun, pertanaman Pinang polikultur Kelapa Sawit yang berumur seragam 10-15 tahun, serta pertanaman monokultur Pinang, Kelapa Dalam, dan Kelapa Sawit yang berusia 10-15 tahun. Alat yang digunakan dalam penelitian ini meliputi Global Positioning Service (GPS), meteran, timbangan, lembar kuisioner, alat perekam, dan kamera.

Penelitian ini menggunakan metode survey pada lahan petani yang ditanami polikultur Pinang dengan Kelapa Dalam, dan Pinang dengan Kelapa Sawit,serta pertanaman monokultur Pinang, Kelapa Dalam, dan Kelapa Sawit. Lokasi penelitian ini dipilih secara sengaja dimana lokasi-lokasi tersebut terdapat budidaya tanaman polikultur Pinang dengan Kelapa Dalam, Pinang dengan Kelapa Sawit, dan pertanaman monokultur Pinang, Kelapa Dalam, dan Kelapa Sawit.

Penentuan pohon sampel dilakukan dengan metode seperti yang dijelaskan oleh Gunawan(2013). Bila jumlah populasi tanaman lebih dari 100 maka tanaman sampel sebanyak $15 \%$, sedangkan bila populasi kurang dari 100 maka tanaman sampel sebanyak 50\%. Penentuan nomor pohon sampel menggunakan metode sampling sistemik sebagai berikut: $k=\frac{N}{n}, \mathrm{~K}$ adalah peningkatan nomor pohon sampel, $\mathrm{N}$ adalah jumlah tanaman, dan $\mathrm{n}$ adalah jumlah tanaman sampel. $k=\frac{220}{40}=5,5$ nilai $\mathrm{K}$ dibulatkan menjadi 6. Berikutnya menyiapkan lotere dengan nomor 1 sampai 9.Jika pengambilan pertama didapat nomor 5, maka sampel pertama adalah tanaman nomor 5 dan sampel berikutnya ditambah dengan angka 6. Contoh: bila tanaman pertama adalah 5 maka tanaman sampel berikutnya adalah, $11,17,23, \ldots$.dan seterusnya sampai 40 tanaman.

Peubah yang diamati adalah :

1. Fisik tanaman berupa :

a. Populasi $\left(\right.$ pohon $\mathrm{ha}^{-1}$ ), menghitung jumlah tanaman monokultur dan polikultur Pinang, Kelapa Dalam dan Kelapa Sawit pada luasan 1 hektar;

b. Tinggi tanaman $(\mathrm{m})$, pengukuran tinggi batang dilakukan dilapangan dengan menggunakan meteran. Tinggi batang dari pangkal batang sampai ke tajuk menggunakan galah/ bambu,

c. Tingkar batang $(\mathrm{cm})$, pengukuran lingkaran batang dilakukan dilapangan dengan menggunakan meteran. Posisi lingkar batang yang diukur adalah setengah meter dari pangkal batang.

2. Umur mulai produksi (tahun), untuk mengetahui umur tanaman mulai berbuah maka dilakukan wawancara kepada petani.

3. Estimasi produksi dan produktivitas pertanaman monokultur dan polikultur Pinang, Kelapa Sawit, dan Kelapa Dalam $\left(\mathrm{kg} \mathrm{ha}^{-1} \operatorname{tahun}^{-1}\right)$ dilakukan dengan cara menimbang hasil produksi monokultur dan polikultur. 
Jurnal Media Pertanian Vol. 4 No. 1 Tahun 2019 Hal. 8 - 18

Media Komunikasi Hasil Penelitian dan Review Literatur Bidang Ilmu Agronomi ISSN print $2503-1279$

ISSN online $2581-1606$

Estimasi produktivitas $=$ Rata-rata produksi plot $\times$ jumlah panen 1 tahun $\times$ populasi per hektar

4. Nilai NKL polikultur

a. Pinang dengan Kelapa Dalam dan Kelapa Sawit, dilakukan dengan cara menghitung angka NKL semua plot pengamatan. Nilai NKL polikultur Pinang dengan Kelapa Dalam sebagai berikut (Mead dan Willey, 1980).

$$
N K L=\frac{A 1}{A 2}+\frac{B 1}{B 2}
$$

Dimana $\mathrm{NKL}=$ nisbah kesetaraan lahan, $\mathrm{A}_{1}=$ hasil Pinang pada pertanaman polikultur, $\mathrm{A}_{2}=$ hasil Pinang pada pertanaman monokultur, $\mathrm{B}_{1}=$ Hasil Kelapa Dalam pada pertanaman polikultur, $\mathrm{B}_{2}=$ hasil Kelapa Dalam pada pertanaman monokultur Kelapa Dalam.

b. Pinang dengan Kelapa Sawit sebagai berikut (Mead dan Willey, 1980).

$$
N K L=\frac{C 1}{C 2}+\frac{D 1}{D 2}
$$

Dimana $\mathrm{NKL}=$ nisbah kesetaraan lahan, $\mathrm{C}_{1}=$ hasil Pinang pada pertanaman polikultur, $\mathrm{C}_{2}=$ hasil Pinang pada pertanaman monokulturPinang, $\mathrm{D}_{1}=$ hasil Kelapa Sawit pada pertanaman polikultur, $\mathrm{D}_{2}=$ hasil Kelapa Sawit pada pertanaman monokultur Kelapa Sawit.

Data hasil pengamatan lapangan dilakukan analisis statistika dengan metode deskriptif dalam bentuk tabulasi dan metode inferensi menggunakan uji tberpasangan. Rumus uji t berpasangan sebagai berikut :

$$
t_{\text {hitung }}=\frac{\overline{x_{1}}-\overline{x_{2}}}{\sqrt{\left\{\frac{\left(n_{1}-1\right) s_{1}^{2}+\left(n_{2}-1\right) s_{2}^{2}}{n_{1}+n_{2}-2}\right\}\left\{\frac{1}{n_{1}}+\frac{1}{n_{2}}\right\}}}
$$

$t_{\text {hit }}=$ Nilai-nilai t hasil perhitungan, $X_{1}=$ produksi Pinang - Kelapa Sawit, $X_{2}$ =produksi Pinang-Kelapa Dalam, $n_{1}=$ Sampel Pinang-Kelapa Sawit, $n_{2}=$ Sampel Pinang - Kelapa Dalam, $S_{1}^{2}=$ deviasi standar produksi Pinang-Kelapa Sawit, $S_{2}^{2}=$ deviasi standar produksi Pinang-Kelapa Dalam

\section{HASIL DAN PEMBAHASAN}

Penelitian ini dilakukan dengan survey di lahan petani yang terletak di desa Sungai Beras kecamatan Mendahara Ulu Kabupaten Tanjung Jabung Timur yang memiliki kebun pinang dengan penanaman pinang, kelapa sawit, dan Kelapa Dalam sistem monokultur dan pinang dengan Kelapa dalam dan pinang dengan kelapa sawit dalam penanaman polikultur. Adapun titik koordinat lokasi penelitian sampel dapat di lihat pada Tabel 1. 
Jurnal Media Pertanian Vol. 4 No. 1 Tahun 2019 Hal. 8 - 18

Media Komunikasi Hasil Penelitian dan Review Literatur Bidang Ilmu Agronomi ISSN print $2503-1279$

ISSN online $2581-1606$

Tabel 1.Lokasi-lokasi sampel petani Desa Sungai Beras Kecamatan Mendahara Ulu

\begin{tabular}{ccl}
\hline Nama Desa & Sampel & Tititk Koordinat \\
\hline & $\mathrm{L}_{1}$ & $\mathrm{~S}=01^{\circ} 07^{\prime} 28.73^{\prime \prime}$ \\
& & $\mathrm{E}=103^{\circ} 32^{\prime} 50.45^{\prime \prime}$ \\
Sungai Beras, Kecamatan & $\mathrm{L}_{2}$ & $\mathrm{~S}=01^{\circ} 07^{\prime} 37.84^{\prime \prime}$ \\
Mendahara Ulu, & & $\mathrm{E}=1^{\circ} 33^{\circ} 33^{\prime} 41.73^{\prime \prime}$ \\
Kabupaten Tanjung & $\mathrm{L}_{3}$ & $\mathrm{~S}=01^{\circ} 07^{\prime} 27.93^{\prime \prime}$ \\
Jabung Timur & & $\mathrm{E}=103^{\circ} 32^{\prime} 49.44^{\prime \prime}$ \\
& $\mathrm{L}_{4}$ & $\mathrm{~S}=01^{\circ} 07^{\prime} 42.16^{\prime \prime}$ \\
& & $\mathrm{E}=103^{\circ} 33^{\prime} 13.10^{\prime \prime}$ \\
& $\mathrm{L}_{5}$ & $\mathrm{~S}=01^{\circ} 08^{\prime} 08.01^{\prime \prime}$ \\
& $\mathrm{E}=103^{\circ} 33^{\prime} 17.85^{\prime \prime}$ \\
\hline
\end{tabular}

Keterangan :

$\mathrm{S}=$ South, E$=$ East, $\mathrm{L}_{1}=$ Monokultur Pinang, $\mathrm{L}_{2}=$ Monokultur Kelapa Sawit, $\mathrm{L}_{3}=$ Monokultur Kelapa Dalam, $\mathrm{L}_{4}=$ Polikultur Pinang dengan Kelapa Dalam, dan $\mathrm{L}_{5}=$ Polikultur Pinang dengan Kelapa Sawit

Dari Tabel 1, dapat dilihat terdapat perbedaan titik koordinat pada setiap lokasi sampel lahan. Pengambilan titik koordinat menggunakan GPS dilokasi lahan sampel, dan setiap perbedaan 1 menit titik koordinat sama dengan jaraknya dengan 30 meter.

\section{Jumlah Populasi dan Fisik Tanaman}

Hasil pengamatan lapangan menunjukkan bahwa populasi tanaman monokultur Pinang ditanam dengan jarak tanam 2,75 x 2,75 m segi empat

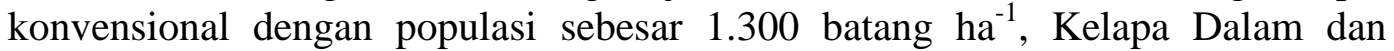
Kelapa Sawit ditanam dengan jarak tanam 8,5 x 8,5 m segi empatkonvensional dengan populasi 138 batang $\mathrm{ha}^{-1}$. Pada pertanaman polikultur Pinang dengan Kelapa Dalam dan Pinang dengan Kelapa Sawit, rata-rata populasi Pinang per hektar sebanyak 360 batang, Kelapa Dalam dan Kelapa Sawit tetap 138 batang ha $^{-}$

1. Populasi tanaman Pinang, Kelapa Dalam, dan Kelapa Sawit monokultur terkategori normal, sedangkan pada pertanaman polikultur, tanaman Pinang sebanyak 360 batang disisipkan diantara tanaman Kelapa Dalam atau Tanaman Kelapa Sawit.Skematis tata tanam disajikan pada Gambar 1. 
Jurnal Media Pertanian Vol. 4 No. 1 Tahun 2019 Hal. 8 - 18

Media Komunikasi Hasil Penelitian dan Review Literatur Bidang Ilmu Agronomi

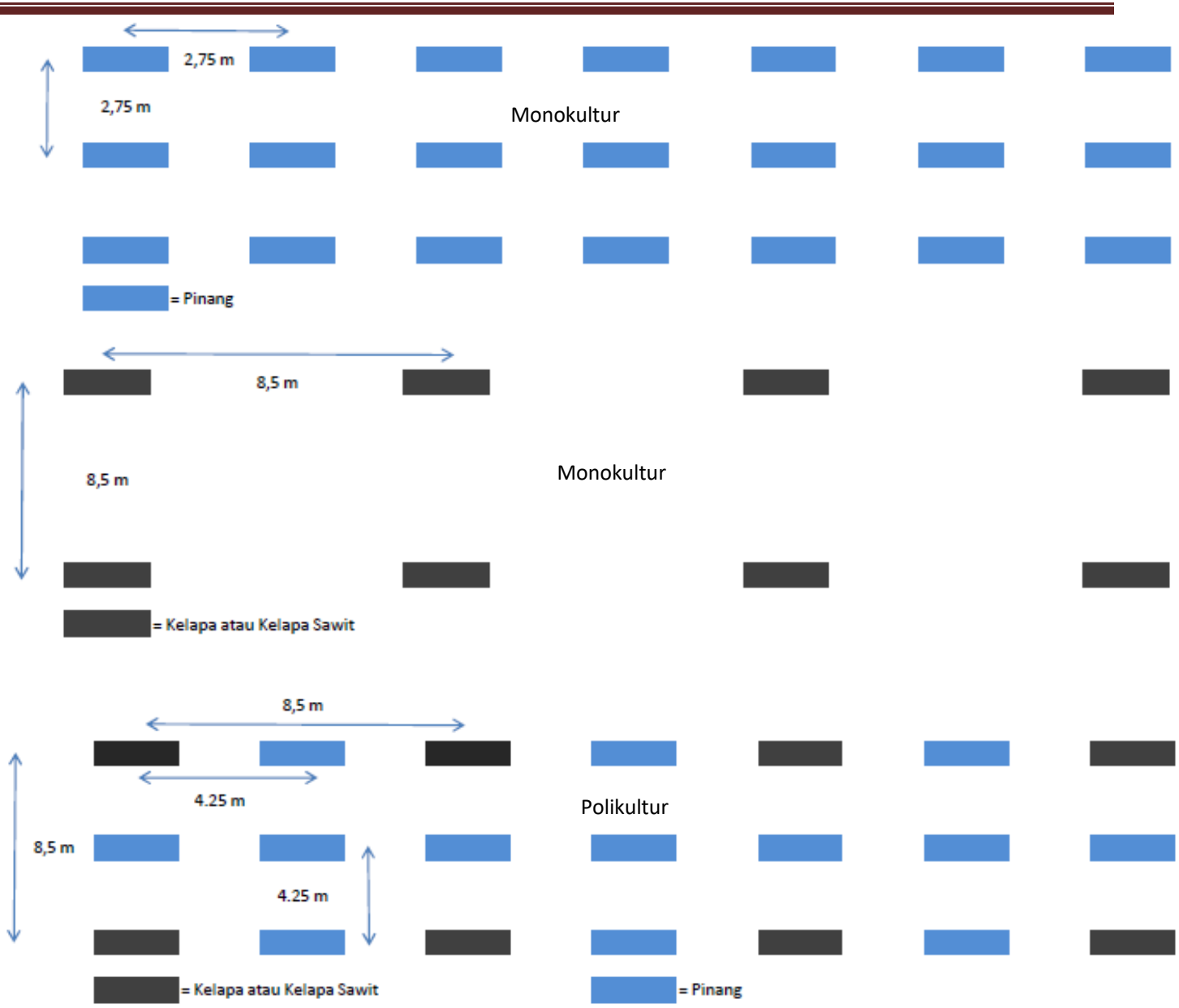

Gambar 1. Skematis tata tanam monokultur Pinang, Kelapa Dalam, dan Kelapa Sawit serta polikultur Pinang Kelapa Dalam atau Pinang Kelapa Sawit

Peningkatan populasi tanaman pada pertanaman polikultur menyebabkan terjadinya kompetisi tanaman spesies yang sama (intraspesifik) Pinang dengan Pinang dan spesies yang berbeda (intraspesifik) Pinang dengan Kelapa Dalam atau Kelapa Sawit yang lain dalam hal ruang tumbuh. Kompetisi cahaya lebih berat terjadi pada tanaman pinang yang disisipkan pada tanaman Kelapa Dalam terutama saat tanaman berumur lebih dari 10 tahun. Pada usia tersebut tanaman Pinang lebih tinggi daripada tanaman Kelapa Sawit, namun lebih rendah dibandingkan tanaman Kelapa Dalam. Hasil pengamatan menunjukkan tinggi tanaman Pinang yang disisipkan pada tanaman Kelapa Dalam 10,6 m dan 10,2 m bila disisipkan diantara tanaman Kelapa Sawit. Persaingan antar tanaman juga berdampak terhadap lingkar batang tanaman. Pinang pada polikultur Pinang Kelapa Dalam memiliki lingkar batang sebesar $45,4 \mathrm{~cm}$ sedangkan pada polikultur Pinang Kelapa Sawit sebesar $34,3 \mathrm{~cm}$.

Dari hasil wawancara dilapangan terdapat perbedaan umur mulai produksi antara tanaman polikultur pinang dengan Kelapa Dalam dan pinang polikultur dengan kelapa sawit. Polikultur pinang dengan Kelapa Dalam berproduksi pada umur 4 tahun sedangkan polikultur pinang dengan kelapa sawit berproduksi pada 
Jurnal Media Pertanian Vol. 4 No. 1 Tahun 2019 Hal. 8 - 18

Media Komunikasi Hasil Penelitian dan Review Literatur Bidang Ilmu Agronomi ISSN print $2503-1279$

ISSN online $2581-1606$

umur 4,5 tahun, hal ini menunjukkan bahwa polikultur pinang dengan kelapa sawit lebih lambat dalam berproduksi. Menurut Kadekoh (2007) dan Kurniawan (2012), jumlah populasi yang terlalu banyak pada sistem polikultur mengakibatkan tanaman berkompetisi dalam penyerapan unsur hara, air, dan cahaya. Kompetisi yang terjadi menyebabkan kebutuhan tanaman untuk berproduksi terganggu, akibatnya tanaman akan sedikit terhambat dalamm proses produksi dan percabangan tanaman.

\section{Produksi, Produktivitas, dan Nisbah Kesetaraan Lahan}

Data hasil pengamatan dilapangan diestimasi untuk menduga produksi dan produktivitas pola tanam monokultur Pinang, Kelapa Dalam, dan Kelapa Sawitserta polikulur Pinang Kelapa Dalam dan Pinang Kelapa Sawit.Hasil estimasi disajikan pada Tabel 2.

Tabel 2.Estimasi produksi, produktivitas, dan nisbah kesetaraan lahan pertanaman monokultur dan polikulturPinang, Kelapa Daam, dan Kelapa Sawit

\begin{tabular}{|c|c|c|c|c|c|c|c|c|c|}
\hline \multirow{2}{*}{$\begin{array}{l}\text { No. } \\
\text { Plot }\end{array}$} & \multicolumn{3}{|c|}{$\begin{array}{l}\text { Produktivitas Monokultur } \\
\left(\mathrm{kg} \mathrm{ha}^{-1} \mathrm{th}^{-1}\right)\end{array}$} & \multicolumn{4}{|c|}{ Produktivitas Polikultur $\left(\mathrm{kg} \mathrm{ha}^{-1} \mathrm{th}^{-1}\right)$} & \multicolumn{2}{|c|}{ NKL Polikultur } \\
\hline & Pinang & $\begin{array}{l}\text { Kelapa } \\
\text { Dalam }\end{array}$ & $\begin{array}{l}\text { Kelapa } \\
\text { Sawit }\end{array}$ & $\begin{array}{l}\text { Pinang } \\
\text { Kelapa } \\
\text { Dalam } \\
\end{array}$ & $\begin{array}{c}\text { Pinang } \\
\text { Kelapa } \\
\text { Sawit } \\
\end{array}$ & $\begin{array}{l}\text { Pinang } \\
\text { Kelapa } \\
\text { Dalam } \\
\end{array}$ & $\begin{array}{c}\text { Pinang } \\
\text { Kelapa } \\
\text { Sawit } \\
\end{array}$ & $\begin{array}{l}\text { Pinang } \\
\text { Kelapa } \\
\text { Dalam } \\
\end{array}$ & $\begin{array}{c}\text { Pinang } \\
\text { Kelapa } \\
\text { Sawit } \\
\end{array}$ \\
\hline 1. & 660 & 840 & 13.440 & 190 & 181 & 784 & 10.080 & 1,22 & 1,02 \\
\hline 2. & 581 & 1.008 & 13.440 & 181 & 156 & 896 & 10.080 & 1,20 & 1,02 \\
\hline 3. & 581 & 952 & 11.760 & 207 & 147 & 840 & 10.080 & 1,24 & 1,11 \\
\hline 4. & 502 & 896 & 12.768 & 164 & 130 & 784 & 13.440 & 1,20 & 1,31 \\
\hline 5. & 607 & 952 & 12.768 & 190 & 130 & 840 & 10.080 & 1,20 & 1,00 \\
\hline 6. & 634 & 1.008 & 12.432 & 164 & 156 & 784 & 10.080 & 1,04 & 1,06 \\
\hline 7. & 554 & 896 & 13.104 & 164 & 173 & 840 & 11.760 & 1,23 & 1,21 \\
\hline 8. & 660 & 896 & 13.440 & 199 & 147 & 840 & 11.760 & 1,24 & 1,10 \\
\hline 9. & 686 & 840 & 11.760 & 207 & 147 & 784 & 11.760 & 1,24 & 1,21 \\
\hline 10. & 686 & 896 & 13.440 & 121 & 121 & 840 & 10.080 & 1,11 & 0,93 \\
\hline Total & $\begin{array}{r}6,15 \\
1\end{array}$ & 9.184 & 128.352 & 1,788 & 1,486 & 8.232 & 109.200 & 11,92 & 10,97 \\
\hline Rerata & 615 & 918 & 12.835 & 179 & 149 & 823 & 10.920 & 1,19 & 1,10 \\
\hline
\end{tabular}

Dari Tabel 2, dapat dilihat bahwa rata-rata produktivitas monokultur Pinang adalah $615 \mathrm{~kg} \mathrm{ha}^{-1}$ tahun $^{-1}$, monokultur Kelapa Dalam 918kg ha ${ }^{-1}$ tahun $^{-1}$, dan monokulturKelapa Sawit $12.835 \mathrm{~kg} \mathrm{ha}^{-1}$ tahun $^{-1}$. Rata-rata Produktivitas Pinang pada polikultur Pinang dengan Kelapa Dalam $179 \mathrm{~kg}^{-1}$ tahun $^{-1}$ dan Kelapa Dalam $823 \mathrm{~kg} \mathrm{ha}^{-1}$ tahun $^{-1}$. Rata-rata Produktivitas Pinang pada polikultur Pinang dengan Kelapa Sawit $149 \mathrm{~kg} \mathrm{ha}^{-1}$ tahun $^{-1}$ dan Kelapa sawit $10.920 \mathrm{~kg} \mathrm{ha}^{-1}$ tahun $^{-}$ ${ }^{1}$.Produktivitas monokultur dan polikultur dibandingkan dan diuji dengan uji tberpasangan.Hasil pengolahan data disajikan pada Tabel 3. 
Jurnal Media Pertanian Vol. 4 No. 1 Tahun 2019 Hal. 8 - 18

Media Komunikasi Hasil Penelitian dan Review Literatur Bidang Ilmu Agronomi ISSN print $2503-1279$

ISSN online $2581-1606$

Tabel 3. Nilai peubah produktivitas dan nisbah kesetaraan lahan dari polikultur Pinang Kelapa Dalam dan Pinang Kelapa Sawit

\begin{tabular}{|c|c|c|c|c|c|}
\hline No. & Peubah & Perlakuan & $\begin{array}{l}\text { Rata-rata } \\
\text { Nilai } \\
\end{array}$ & t-hit & $\mathrm{P}$ \\
\hline 1. & $\begin{array}{l}\text { Produktivitas Pinang } \\
\left(\mathrm{kg} \mathrm{ha}^{-1} \mathrm{th}^{-1}\right)\end{array}$ & $\begin{array}{l}\text { Polikultur Pinang-Kelapa Dalam } \\
\text { Polikultur Pinang-Kelapa Sawit }\end{array}$ & $\begin{array}{l}202 \\
186\end{array}$ & 6,37 & 0,000 \\
\hline 2. & $\begin{array}{l}\text { Produktivitas Kelapa } \\
\text { Dalam }\left(\mathrm{kg} \mathrm{ha}^{-1} \mathrm{th}^{-1}\right)\end{array}$ & $\begin{array}{l}\text { Monokultur } \\
\text { Polikultur Pinang-Kelapa Dalam }\end{array}$ & $\begin{array}{l}918 \\
823\end{array}$ & 2,05 & 0,000 \\
\hline 3. & $\begin{array}{l}\text { Produktivitas Kelapa } \\
\text { Sawit }\left(\mathrm{kg} \mathrm{ha}^{-1} \mathrm{th}^{-1}\right)\end{array}$ & $\begin{array}{l}\text { Monokultur } \\
\text { Polikultur Pinang-Kelapa Sawit }\end{array}$ & $\begin{array}{l}12.835 \\
10.920\end{array}$ & 2,15 & 0,000 \\
\hline 4. & $\begin{array}{l}\text { Nisbah Kesetarahan } \\
\text { Lahan }\end{array}$ & $\begin{array}{l}\text { Polikultur Pinang-Kelapa Dalam } \\
\text { Polikultur Pinang-Kelapa Sawit }\end{array}$ & $\begin{array}{l}1,19 \\
1,10\end{array}$ & 3,38 & 0,003 \\
\hline
\end{tabular}

Berbeda nyata bila $\mathrm{P}<0,005$, Berbeda tidak nyata bila $\mathrm{P}>0,005$

Hasil Uji-t menunjukan produktivitas tanaman polikultur Pinang dengan dengan Kelapa Dalam dan Pinang dengan Kelapa Sawit berbeda sangat nyata (Tabel 3). Dengan jumlah populasi yang sama (360 batang ha ${ }^{-1}$ ), Pinang yang disisipkan pada Kelapa Dalam dapat berproduksi sebesar $202 \mathrm{~kg} \mathrm{ha}^{-1}$ tahun $^{-1}$, jika disisipkan pada tanaman Kelapa Sawit, produksi pinang sebesar $186 \mathrm{~kg} \mathrm{ha}^{-1}$ tahun $^{-}$ 1. Produktivitas Kelapa Dalam turun dari 918 menjadi $823 \mathrm{~kg} \mathrm{ha}^{-1} \operatorname{tahun}^{-1}$, sedangkan produktivitas Kelapa Sawit turun dari 12.835 menjadi $10.920 \mathrm{~kg} \mathrm{ha}^{-1}$ tahun $^{-1}$. Penurunan produktivitas tanaman polikultur juga didapat pada tanaman lainnya seperti didapat oleh Taha dan Mahdy (2014) pada tanaman tomat dan snap bean, Amanullah et al. (2016) pada tanaman jagung dan kacang panjang. Namun keduanya menyatakan bahwa nilai NKL polikultur $>1$.

Penurunan produktivitas tanaman pada pertanaman polikultur disebabkan oleh persaingan antara tanaman. Persaingan cahaya yang dapat mempengaruhi laju fotosintesis serta persaingan unsur hara yang akan mempengaruhi jumlah unsur hara yang dapat diserap oleh tanaman. Menurut Li et al. (1999) jarak tanam yang rapat menyebabkan distribusi akar akan terganggu. Daya jelajah akar Kelapa Dalam pada radius $2 \mathrm{~m}$, sedangkan akar Kelapa Sawit dapat mencapai $3 \mathrm{~m}$. Persaingan hara yang lebih berat terjadi pada tanaman Pinang yang disisipkan pada tanaman Kelapa Sawit, dampak dari persaingan ini dapat diketahui dari produksi tanaman Pinang yang disisipkan pada tanaman Kelapa Sawit. Pada jumlah populasi yang sama (360 batang) produksi Pinang turun $8,6 \%$ bila disisipkan diantara tanaman Kelapa Sawit.

Penurunan produktivitas tanaman merupakan dampak negatif pertanaman polikultur. Kondisi ini merupakan kondisi yang wajar apalagi tidak ada tanaman yang menstimulasi tanaman lain (seperti Legum yang menstimulasi tanaman lain melalui kelebihan Nitrogen). Pinang, Kelapa Dalam, dan Kelapa Sawit merupakan tanaman palmae dengan model perakaran serabut yang menyebar ke samping sehingga menyebabkan terjadinya kompetisi akar dalam mengambil unsur hara. Dampak positif dari pertanaman polikultur adalah masyarakat dapat memanen Pinang dan Kelapa Dalam atau Kelapa Sawit pada lahan yang sama.

Penurunan produktivitas tanaman belum tentu berkorelasi positif dengan produktivitas lahan. Pada pengamatan peubah NKL, diketahui bahwa dari 10 plot 
Jurnal Media Pertanian Vol. 4 No. 1 Tahun 2019 Hal. 8 - 18

Media Komunikasi Hasil Penelitian dan Review Literatur Bidang Ilmu Agronomi ISSN print $2503-1279$

ISSN online $2581-1606$

yang diuji, NKL polikultur Pinang Kelapa Dalam sebesar 1,19 dan Pinang dengan Kelapa sawit sebesar 1,10. Data ini bermakna bahwa polikultur Pinang dengan Kelapa Dalam meningkatkan keuntungan 19\% di bandingkan monokultur Pinang dan monokultur Kelapa Dalam.Nilai NKL Pinang dengan Kelapa sawit sebesar 1,10 bermakna bahwa polikultur Pinang dengan Kelapa Sawit memberikan keuntungan 10\% lebih tinggi dibandingkan monokultur Pinang dan monokultur Kelapa Sawit. Sejalan dengan pendapat Mead dan Willey (1980), bahwa nilai rata-rata NKL yang $>1$ menggambarkan bahwa pertanaman campuran menguntungkan jika ditanam secara polikultur dibanding pertanaman monokultur pada luas lahan yang sama. Hasil Uji-t menunjukan NKL Pinang dengan Kelapa Dalam dan pinang dengan kelapa sawit berbeda sangat nyata, dengan demikian lebih di anjurkan polikultur pinang dengan Kelapa Dalam di bandingkan Pinang dengan Kelapa Sawit.

\section{KESIMPULAN}

Terjadi persaingan interspesifik dan intraspesifik pada polikultur Pinang Kelapa Dalam dan Pinang Kelapa Sawit yang ditunjukkan dengan menurunnya Produksi dan produktivitas dari monokultur ke polikultur. Besaran penurunan produksi Pinang dari monokultur ke polikultur sebesar 8,6\%.

Nilai NKL Polikultur Pinang Kelapa Dalam sebesar 1,19 dan NKL polikultur Pinang Kelapa Sawit sebesar 1,10. Polikultur Pinang Kelapa Dalam dapat meningkatkan keuntungan sebesar $19 \%$ dan polikultur Pinang Kelapa Sawit meningkatkan keuntungan 10\% dibandingkan pertanaman monokultur.

Hasil Uji-t menunjukan bahwa NKL Pinang Kelapa Dalam dan Pinang Kelapa Sawit berbeda sangat nyata. Polikultur lebih dianjurkan dibandingkan monokultur dan polikultur Pinang Kelapa Dalam lebih baik dibandingkan Pinang Kelapa Sawit.

\section{DAFTAR PUSTAKA}

Amanullah, F. Khan, H. Muhammad, A. U. Jan and G Ali. 2016. Land Equivalent Ratio, Growth, Yield and Yield Components Response of Mono-cropped vs. Inter-cropped Common Bean and Maize With and Without Compost Application. Agric. Biol. J. N. Am. 7(2):40-49

Beets, W.C. (1990). Raising and Sustaining Productivity of Smallholder Farming Systems in the Tropics. Alkmaar, Holland: AgBe Publishing.

Dinas Perkebunan Provinsi Jambi, 2017. Statistik Perkebunan Provinsi Jambi Tahun 2017.

Gunawan, M A. 2013. Statistik untuk Penelitian Pendidikan. Parama Publishing. Yogyakarta.

Hatta, M. 2015. Pengaruh Tipe Jarak Tanam terhadap Anakan, Komponen Hasil, dan Hasil Dua Varietas Padi pada Metode SRI. J. Floratek. 6: 104-113.

Kadekoh. 2007. Optimalisasi Pemanfaatan Lahan Kering Berkelanjutan dengan Sistim Polikultur. Prosiding Seminar Nasional Pengembangan Inovasi Lahan Marginal. Halaman 27 - 33 
Jurnal Media Pertanian Vol. 4 No. 1 Tahun 2019 Hal. 8 - 18

Media Komunikasi Hasil Penelitian dan Review Literatur Bidang Ilmu Agronomi ISSN print $2503-1279$

ISSN online $2581-1606$

Li, L., J. Sun, F. Zhang, T. Guo, X. Bao, F.A. Smith, and S.E. Smith. (2006). Root distribution and interactions between intercropped species. Oecologia 147: $280-290$

Mead, R., dan Willey, R. W. (1980). The concept of a 'land equivalent ratio'and advantages in yields from intercropping. Experimental Agriculture, 16(03), $217-228$

Nasamsir dan Harianto. 2018. Pertumbuhan Dan Produktivitas Lahan Tumpang Sari Tanaman Pinang (Areca catechu L.) dan Kopi (Coffea sp.). Jurnal Media Pertanian 3 (2): 61-71

Nasmasir dan Irman. 2018. Pertumbuhan dan Produksi Tanaman Pinang dan Kelapa Sistem Tumpangsari. Jurnal Media Pertanian 3 (1): 1-9

Nengsih, Y. 2016. Tumpangsari Tanaman Kelapa Sawit (Elaeis guineensis Jacq.) dengan Tanaman Karet (Hevea brassiliensis L.). Jurnal Media Pertanian 1 (2): $69-77$

Sopandi dan Trikoesoemaningtyas. 2011. Pengembangan Tanaman Sela di Bawah Tegakan Tanaman Tahunan. Iptek Tanaman Pangan 6(2) : 168 - 182

Taha, E.M. dan A.M. El-Mahdy. 2014. Land Equivalent Ratio as a Reference for Relative Crowding Coefficient and Aggressivity of Intercropped Plant Species. Middle East Journal of Agriculture Research, 3(3): 576-585

Kurniawan, H. 2012. Strata Tajuk dan Kompetisi PertumbuhanCendana (Santalum album Linn.) di Pulau Timor. Jurnal Penelitian Kehutanan Wallacea 1(2): 103-115 